\title{
The transcendence of the face: A semiotic-linguistic path
}

\author{
Ugo Volli ${ }^{1}$
}

\begin{abstract}
This paper starts with an examination of the terms used to designate the face in different languages, in particular in Italian, comparing these with the definitions provided by some authoritative dictionaries as well as with their etymology. This exploration yields some remarkable results: firstly, it appears that the face is indeed a term that has a material meaning, but at the same time it is a social object; secondly, the importance of the communicative function emerges, which makes the face similar to the mask and in some ways to the arbitrariness of language. All this suggests that the philosophical status of the face is that of 'transcendence' which is a condition of that state of freedom that we attribute to ourselves and that can be defined as 'human exception'.
\end{abstract}

Keywords: face; lexicon; social objects; metaphor; Levinas; transcendence

\section{Introduction}

Semiotics describes texts and analyses their conditions of use and the effects of meaning they produce. This has obvious social utility, because it allows us to classify and study communication occurring in a certain society. Used in a more radical way, however, semiotic analysis allows us to study the social rules of signification and thus to understand the mindframes prevalent in different societies, because all communication in every culture is formulated according to syntactic, semantic and pragmatic categories characteristic of that society. These categories always involve a degree of arbitrariness, even in the extreme case in which communication consists of simple material objects exhibited to indicate themselves, as demonstrated by the inhabitants of Laputa in Gulliver's Travels. These objects are in fact assumed as signifiers, common names or prototypes of the set of objects to which they belong in that culture. These prototypes, in turn, depend on ontology or implied metaphysics (Quine 1960). Actually, everything that

1 Department of Philosophy and Education Science, University of Turin, Torino, Italy; e-mail: volli.ugo@gmail.com. 
works as a sign - every message - is always brought to communication through the mediation of the "primary modelling system" of its society, namely of language (Lotman 1967). Language determines and limits the very possibility of signification, even the silent one. A fundamental condition for semiotic research is leaving behind of the naive ethnocentric naturalization of social objects and of posing the problem of their origin and their transformations in relation with language, by studying texts, but first and foremost by questioning the lexicon.

For this reason, it is indispensable that semiotics should include a philosophicallinguistic approach in its typological studies, at least if we define philosophy of language not as analytic philosophy usually does (Beaney 2013: 13), but as a type of research that, operating from within a language, attempts to describe and understand, through the use of the language itself, the fundamental semantic choices that are arbitrarily or historically made by its culture. So, in order to understand what a certain society means and communicates through "social things" such as 'love, 'religion', 'money' (Ferraris 2009; Searle 1995), but also through "natural things" that are socially semanticized and communicatively defined such as 'child', 'dog', 'sea', it is necessary to probe the words that describe and model them. They work, actually, by cutting their object (often a set of objects unified in a social category just by that word) out of world continuity; interrogating words means trying to understand the cultural or empirical logic underlying this clipping. This is certainly also true for such an entity as the 'face' which, as part of the human body, is certainly material - yet it is also highly socially defined, as we will see soon. To try to unravel the paradoxes and aporias that surround this socio-material object, it is relevant to study the word and its use, which is done in what follows mainly on the basis of the Italian language with some references to other languages.

\section{An ill-defined entity}

Let us start from a paradox. Lexemes corresponding to our 'face' are found in numerous languages: linguistic literature does not mention examples of a lack of relevant terms in any language. From a naive point of view, this word is very easy to understand, everyone knows it in all contemporary major cultures - but it is difficult to define exactly in precise conceptual terms. It is worth starting with the definitions of the word offered in some dictionaries:

OED: “The front part of a person's head from the forehead to the chin, or the corresponding part in an animal."

Merriam Webster: "The front part of the head that in humans extends from the forehead to the chin and includes the mouth, nose, cheeks, and eyes." 
Cambridge: "The front of the head, where the eyes, nose, and mouth are."

Garzanti: "La parte anteriore della testa umana, dalla fronte al mento."

Larousse: "Région limitée en haut par le cuir chevelu, sur les côtés par les oreilles et en bas par le cou."

Duden: "Besonders durch Augen, Nase und Mund geprägte Vorderseite des menschlichen Kopfes vom Kinn bis zum Haaransatz."

All these definitions, and the many other very similar ones that are found in other languages, have a certain oddity to them. The face is defined as part of the head or in some cases of the human body, characterized by the presence of certain organs, such as the nose, eyes and mouth, and bounded by other physical units such as the chin, forehead and ears. However, these smaller objects are also part of the face; only in rare cases does the definition use external details such as the neck and the hairline. The strangeness is due to the fact that if you look for the definitions of all these parts or boundaries that define 'face', you are sent back to the face: a vicious circle emerges. To give just a couple of examples, according to the Cambridge dictionary 'forehead' is "the flat part of the face, above the eyes and below the hair"; for Merriam Webster, 'nose' is "the part of the face that bears the nostrils and covers the anterior part of the nasal cavity", and so on. ${ }^{3}$ In conclusion, 'face' is defined through its parts, and its parts through the face. This is certainly an example of a very widespread problem of dictionaries, which in turn essentially depends on the labyrinthine format of the semantics of natural languages and probably of human cognition: it is a well-known problem in semiotics, widely discussed at least since the observations made in the chapter "Dictionary vs. encyclopedia" in Eco 1983. Formal semantics, cognitive sciences, artificial intelligence studies are also well aware of this. Yet in this case the circularity is not extended, and thus vague, as in the regular rhizomatic structure of lexical semantics, but appears immediately at the first step and we are led to think that it depends on a difficulty concerning the specific object.

Actually, the face is neither a distinct nor homogeneous anatomical reality: nose, eyes, lips, forehead have different origins in the development of the embryo and are made up of different tissues under the skin. The colours, the textures, the shapes of these details vary to a considerable degree. The upper and lateral limits of the face

2 The definitions have been obtained from the following sources, last accessed on 22 February 2021: Oxford: https://www.lexico.com/definition/face; Merriam Webster: https:// www.merriam-webster.com/dictionary/face; Garzanti: https://www.garzantilinguistica.it/ ricerca/?q=faccia\%201; Larousse: https://www.larousse.fr/dictionnaires/francais/face/32561?q= Face\#32473; Duden: https://www.duden.de/rechtschreibung/Gesicht_Aussehen_Miene_Sinn. La 3 Cambridge: https://dictionary.cambridge.org/dictionary/english/forehead; Merriam Webster: https://www.merriam-webster.com/dictionary/nose. Accessed on 22 February 2021. 
are variable, because they depend on the way the hair is arranged. The different parts of the face do not even have a common aspect. The face cannot be defined, for example, as the whole hairless part of the head, because in many adult males conspicuous parts of it would be naturally hairy due to cultural conventions. It is worth introducing here a complex anatomical description proposed by the most authoritative Italian encyclopedia:

Part of the man's head located inferior to the front of the skull. It is continuous with the base of the skull and is supported by a complex bony scaffold, consisting of the upper jaw, the zygomatic arch, the lacrimal, the lower turbinates, the nasal bone, the palatine bones and the lower jaw. These bones delimit cavities in which the peripheral organs of the three senses (sight, smell, taste) and the initial tracts of the respiratory and digestive systems are located. The $\mathrm{f}$. is equipped with masticatory muscles and numerous cutaneous muscles, which regulate the opening of the various orifices present (e.g. lips, nostrils), move the eyelids and, by modifying the skin folds, cause changes in expression. A single nerve, the facial nerve, innervates all the muscles, while the sensitivity at the level of the skin is mainly due to the branches of the trigeminal nerve. Vascularization is largely ensured by the facial artery. ${ }^{4}$

In short, the face is not really a scientific object or a natural kind identified as such by science (as are chemical elements such as iron, or animal species such as the lynx, or organs such as the thyroid) (Daly 1998; Bird, Tobin 2008). It is a cultural clipping of a real biological entity, the head, and, therefore, somewhat puzzling as a material social object which, although it has a universal presence in human populations, can also be extended to the animal world according to some authoritative voices (Darwin 2009[1872]). Here, one cannot fail to notice an important semantic tension between universality and arbitrariness.

4 "Parte della testa dell'uomo situata inferiormente alla parte anteriore del cranio. Si trova in rapporto di continuità con la base del cranio ed è sostenuta da una complessa impalcatura ossea, costituita dall'osso mascellare superiore, dallo zigomatico, dal lacrimale, dal turbinato inferiore, dal nasale, dal palatino e dal mascellare inferiore. Queste ossa delimitano cavità nelle quali hanno sede gli organi periferici di tre sensi (vista, olfatto, gusto) e i tratti iniziali degli apparati respiratorio e digerente. La f. è dotata di muscoli masticatori e di numerosi muscoli pellicciai, che regolano l'apertura dei vari orifizi presenti (per es. labbra, narici), muovono le palpebre e, modificando le pieghe cutanee, determinano i cambiamenti di espressione. Un solo nervo, il facciale, innerva tutti i muscoli, mentre la sensibilità al livello della cute è dovuta soprattutto alle diramazioni del nervo trigemino. La vascolarizzazione è assicurata in massima parte dall'arteria facciale." Source available at: https://www.treccani.it/encyclopedia/face/ Last accessed on 22 February 2021. Translations from Italian are by the author of the article, unless indicated otherwise. 


\section{The surface of perception and communication}

It is worth looking further into the definitions given above to try to understand our object better. 'Face' is described through elements that are part of it. I have already pointed out the paradoxical character of this kind of definition, which leads to the difficulty of finding a notion's semantic content by specifying autonomous pertinent traits characterizing it. Yet if we take a closer look at the parts of the face that are used to define it, we can find two groups: on the one hand, there are limit elements, i.e. those parts of the body that mark the boundaries of the face from the inside and only sometimes from the outside: the chin or the neck (downward); the forehead or the hair (upward); the ears or the hair (sideways). On the other hand, we find some objects that are on the face, which do not mark its boundaries, but are its conspicuous parts: the mouth, the nose, the eyes and, again, the ears. It is worth noting that these elements are only a subgroup of all notable parts of the face: no definition mentions, for example, the cheekbones, the cheeks or the eyebrows.

Actually, the elements mentioned all serve as the site of sense organs, indeed of all the localized senses: sight, smell, hearing, taste, and partly also touch, a sense spread over the whole body. It is worth adding a consideration which is important from a communicative point of view: these organs are not purely passive receptors, which remain immobile just allowing themselves to be hit by sound, light or chemical stimuli. In fact, each of them (with the partial exception of the ears, which in humans are mostly immobile) acts to search, select and capture its own stimuli. The mouth opens or closes, lips protrude or retract, the tongue moves and explores, the cheeks swell or are squeezed in, exposing the teeth in order to bite or hiding them, etc. The lids become closed or the eyes widen, orienting themselves in one direction or another, stare sharply at something or wander distractedly. The nose can also dilate the nostrils or become wrinkled.

These different activities are mostly natural consequences of choices of value, following the logic of appreciation or rejection, of pleasure or disgust, of interest or boredom. Yet at the same time, acting this way the sense organs express these choices. These acts involve muscles and skin even beyond the actual location of the sense organ: the wrinkling of the nose extends to the tension of the cheeks and of the forehead; uncovering the teeth causes a visible contraction that reaches up to the cheekbones, the cheeks, the chin. So, the whole face, or its major parts, is involved in these motions, often allowing an organ to replace the others from an expressive point of view: for example, we often and rightly speak of 'smiling with the eyes. All these complex actions are visible and convey values. They are called 'expressions' because they project the person's thymism outward: this is where the semiotic terminology relating to the signifier comes from. From this point of view, the face is the prototype of every axiologized support of signification. 
In a species as strongly characterized by the density of social interactions and the constant interest in synchronization with others as that of the humans, this relationship between the activity of the sense organs and the perception of values can easily engender voluntary expressions, communication of values, even beyond the physical stimuli that generally give rise to the action. For this reason, the face, and in particular the sense organs that reside there, provide the place where a significant part of pre-technical human communication is concentrated: verbal communication, because the mouth is obviously the location of speech and the ears are the site of listening, but also all non-verbal communication: smiles, looks, laughter, grimaces, surprises, blushing and turning pale etc. It is the body part via which almost all the perception of the world enters the awareness of the subject, as well as the one that sends out most of our messages. It is the most important device for communicating with our fellow human beings. Therefore, it is the area that others look at to identify feelings and mental states, and that we therefore try to control better. Since human beings are used to knowing the face in detail, it is also the most important identification interface, the one with the help of which we recognize who is in front of us and that is portrayed in "identity documents". However, these empirical considerations never appear in the dictionary definitions of the face, no doubt due to their complexity.

These definitions contain yet another focal point, namely the presence of a directional indication: the face is the "forepart" of the head, often also referred to as the "front" of the head. ${ }^{5}$ This clarification is also important, because it evidently refers to the common experience of the indexical capacity of this part of the body, that is, of its being directed towards something or someone. Turning your face in a certain direction, that is, "facing it", shows interest (which is etymologically 'inter esse', 'being among': facing something seems to imply metaphorically the act of going near or into that object). What is faced becomes the privileged object of attention and dialogue.

All these dictionary definitions therefore imply (but never explicitly recognize) the role of the face as the input-output centre of communication and human perception. There are undoubtedly evolutionary reasons why not only humans, and not just primates or mammals, but a substantial share of all multicellular animals - including amphibians, reptiles, fish, certain mollusks and even insects - concentrate the organs of sense, nutrition and communication in one single front area of the body - that is, towards the direction in which these

5 It is perhaps not without interest to note that the same directional indication of 'front' as 'anterior' incidentally has its etymology in a facial metaphor. The Latin 'frons', from which the term derives, in fact meant 'forehead'. 
animals predominantly move. This concentration is what all human cultures have included in their lexicon with expressions that refer to the biologically artificial, yet functionally founded notion of 'the face'.

This strongly communicative dimension is also the reason why in different cultures the face is also often used as an inscription support for make-up and tattoos. Also, facial hair (beard, moustache, eyelashes, eyebrows) cut in different shapes performs the same communicative function. All these elements amplify the variable production of nonverbal communication by the muscles and skin. Face inscription as a tool used to intensify and modify expressions is a technique well known to mask makers and makeup professionals.

Furthermore, the recognizability of the face and its expressive function mean that even its stable characteristics, such as the width and shape of the sense organs and their details, the overall geometric shape, the colour, etc., are often treated (naively, or according to various theories of "body language") as bearers of meaning. It is clear that this diagnostic attitude to the shape of the face also involves several dangers: not only that of pseudoscience, but also racism, or at least perceptive ethnocentrism, which is difficult to escape from, given that it is a powerful force already at the level of animal evolution (Prum 2017).

What emerges from everything said above is a strong textual dimension of the face, an intertwining of components that produce meaning according to a clear semiotic articulation. It is easy to identify a plane of expression in which the muscles, the skin, etc., make up the substance and what in common parlance is called the 'facial expression' constitutes the form; and then there is a plane of content whose substance is the thymic dimension of subjectivity and whose form is its articulation in a semantics of passions dependent on the particular culture. It is worth noting here that facial expressions are not to be examined in isolation, because they are complex on the level of the signifier, but above all strongly influenced by the context. An important example of this complexity is the "Kuleshov effect" that received its name from the Russian director who showed in a series of experiments that the same image of a character's face with a neutral expression was generally interpreted as sad, hungry, in love, etc., when edited together with cinematic sequences that suggested a story in which he had to assume those passions in order to fulfill his actant role (Riley 1998). 


\section{The linguistic comparison}

These stratifications of meaning are expressed in a strong complexity of linguistic signifiers that correspond to the concept of 'the face.' They are very often related to the idea of seeing and being seen (Greek $\pi \rho$ ó $\sigma \omega \pi \mathrm{ov}$ - pròsopon; French visage),

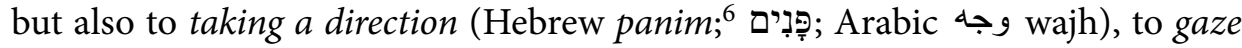
(German Gesicht), to form or shape (Latin facies, Polish twarz), to head (Spanish cara), to beak (Spanish rostro), to the being in front (Chinese 面對 Miàn dui), to cheek (Russian litso). This remarkable etymological diversity, which is also found within rather narrow linguistic families that are often rather uniform in naming parts of the body, also testifies to the cultural construction of the notion of 'the face'.

It is worth investigating at least some of these differences, considering the case of the Italian language, which is characterized by a notable richness of terminology relating to the subject and whose derivations are generally well documented. The three main lexemes in Italian that directly and denotatively refer to the face are 'faccia', 'volto', and 'viso'. However, one of the most authoritative thesauri of the Italian language, Dizionario dei sinonimi e dei contrary, lists 18 words for 'face', some of which are rather rare or connotative, the latter often taken from the nomenclature of animals: "faccia, viso, volto, muso, grinta, grugno, grifo, ghigna, ceffo, mostaccio, mutria" (Gabrielli 1967: 286), while on a more abstract side, there is a second part of the list with words that allude transparently to image, look and form: "fisionomia, sembiante, fattezze, lineamenti, tipo, profilo, sgorbio, effige".

The etymologies of the three main synonyms are quite clear. 'Faccia' comes from the "Latin facies, 'shape, look, face', akin to facerre 'do"; ' viso' from the "Latin visus -us, properly 'sight, look, aspect', derivative of vidère 'to see". Things are more complicated only concerning ' volto'. There is an evident relationship with the Latin "vŭltus, 'face, aspect",' which means 'face', but also 'look, 'expression', 'physiognomy', even 'portrait', as well as 'side, 'surface, and has a form 'voltus' (Campanini-Carboni 1993: 1735). This Latin word could have a close relationship with 'volutus', the perfect participle of 'volvere' ('rolling'), as indeed in Italian there is a word 'volto' ('facing, 'addressed to'), the past participle of 'volgere' ('turn'), which derives directly from that Latin verb. It could therefore be related to our name 'volto' ('face'). In this case the etymological meaning of this word would be that of 'being turned' in a certain direction, heading towards it, or offering a certain side of the head to the eye. Some believe that the two words have no relationship and the 'volto' that indicates the face can be "traced back to the root *uel, 'to see"'

6 For a careful examination of biblical Hebrew, I refer to Volli 2020.

7 The sources: https://www.treccani.it/vocabolario/face_\%28Sinonyms-e-Contrari\%29/; https://www.treccani.it/vocabolario/volto/; last accessed on 22 February 2021. 
(Cortellazzo, Zolli 1988: 1452). Others argue for the convergence of the two forms (Colonna 1997: 412). At the emergence of Italian literature, Dante Alighieri was already aware of this ambiguity and made it the subject of a famous paronomastic pun:

...e non mi si partia dinanzi al volto

anzi 'mpediva tanto il mio cammino

ch'i' fui per ritornar più volte volto.

$\left(\right.$ Inferno, I, 36) ${ }^{8}$

It is worth mentioning the general comparison that the Treccani Dictionary of Synonyms makes of these terms and of the other more connotative ones, as this certainly clarifies the linguistic subtleties involved:

Among the terms that indicate the front part of a human head, faccia is the most
common and familiar one (and in fact it is used in numerous expressions, phrases
and idioms [...]); viso has a slightly more sustained tone; volto is more literary
$[\ldots]$. Other terms are available in a derogatory or ironic tone: ceffo, grugno and
muso. Ceffo is the most offensive term of the three, and is used to indicate a sinister,
unpleasant or disreputable person [...]. Grugno is properly the snout of the pig, and
is used in a figurative sense to indicate both an ugly appearance $[. .$.$] , someone who$
one would gladly punch [...], and a sullen or angry expression $[. .$.$] . Muso is a term$
that designates the front part of the head of any animal, and can be metaphorically
extended to humans both in a derogatory sense $[. .$.$] and as a term of endearment$
(especially with the altered musetto and musino). ${ }^{9}$

It is worth pointing out that 'ceffo' comes "from the old French chief, that is 'head"; 'grifo' "from the Latin grȳpus, meaning with a big nose", which, however, is the name of a bird of prey that we still call 'griffon'; 'grugno' "from the Latin grunium, probably from grunnìre 'grunt'; to compare with the French groin 'snout', Romansh

8 "refused to back away from me but so impeded, barred the way, that many times I turned to go back down." (translation by Robert Hollander and Jean Hollander)

9 https://www.treccani.it/vocabolario/faccia-finestra-di-approfondimento_\%28Sinonimie-Contrari\%29/: Tra i termini che indicano la parte anteriore della testa dell'uomo, f. è quello più com. e fam. (e infatti è usato in numerose espressioni, locuz. e modi di dire) [...] viso è di tono leggermente più sostenuto, volto è più lett.[...] In tono spreg. o iron. sono disponibili altri termini: ceffo, grugno e muso. Ceffo è il termine più offensivo dei tre, e si usa per indicare una persona dall'aspetto sinistro, sgradevole o poco raccomandabile[...]. Grugno è propriam. il muso del maiale, e viene usato in senso fig. per indicare sia un brutto aspetto[...] Muso è infine il termine che designa la parte anteriore della testa di qualunque animale, e può essere esteso metaforicamente all'uomo sia in senso spreg. [...], sia in senso vezzeggiativo (soprattutto con gli alterati musetto e musino. Last accessed on 22 February 2021. 
gruogn 'chin' and Romanian grui 'top of the hill, hill'"; and that, at last, 'muso' derives from the "late Latin $m \bar{u} s u(m)$, of unknown etymology"; but it is worth adding that "according to some [it comes] from (vultus) musus ("prominent mouse face'), ${ }^{10}$ from muricu, extracted from mus ('mouse'). According to others from morsus, caming from a Germanic $\operatorname{root}^{*} m u$ " (Colonna 1997: 254).

Also, in the classification of the Treccani Dictionary we can see a division into two parts of the semantic field, one being more characteristic, connotative and metaphorical, and the other more abstract and denotative:

By faccia, viso and volto you may wish to mean the outward appearance, facial features in general (his faccia tells me something, maybe we have already met?). In this case we can speak of aspetto, ['appearance'] (it has a familiar aspetto), fattezze ['features'] or fisionomia ['physionomy'] (all three more general terms, which can refer to features that are not only facial [...] or, more specifically for the characteristics of the face, of lineamenti ['outlines']. [...] Aspetto ['appearance'], more generically and less directly than faccia, also refers to the way of posturing, of appearing. Apparenza ['appearance'], aria ['look'] or espressione ['expression'] are also used in the same meaning. [...] Atteggiamento ['posture'] is rarely limited to the outward appearance, mostly indicating an overall inner way of being that also transpires outwardly [...]. Cera ['mien'] is more specific for health conditions: having a good or bad cera indicates the complexion and facial expression of those who feel good or bad. ${ }^{11}$

The Italian semantic field of 'face' is thus characterized in three layers. First of all we have a nucleus of three words (which in many other languages are one, as in the English 'face'): 'faccia', 'viso', 'volto', which are largely overlapping, but not perfectly equivalent - you cannot say *' viso a viso' as you say 'faccia a faccia' ('face to face'); the 'sacro volto' ('sacred face') is not the *'sacra faccia'; there are affectionate diminutives of 'faccia' and 'viso' (faccina, visino) but not of 'volto', etc.

10 Sources: https://en.wiktionary.org/wiki/ceffo; https://it.wiktionary.org/wiki/grifo; https://www.treccani.it/vocabolario/faccia-finestra-di-approfondimento_\%28Sinonimi-eContrari\%29/; https://www.garzantilinguistica.it/ricerca/?q=muso https://en.wiktionary.org/ wiki/grugno were accessed on 22 February 2021.

11 Con $f$., viso e volto si può anche voler intendere l'aspetto esteriore, i tratti facciali in generali (la sua $f$. mi dice qualcosa, forse ci siamo già incontrati?). In questo caso si può parlare di aspetto (ha un aspetto familiare), fattezze o fisionomia (tutti e tre termini più generali, che possono rimandare a caratteristiche non soltanto facciali [...] oppure, più specificamente per le caratteristiche del volto, di lineamenti [...]. Aspetto, più genericamente e meno direttamente di f., rimanda anche al modo di atteggiarsi, di apparire: oggi non hai un bell'aspetto, forse ti senti poco bene? In questo stesso sign., sono usati anche apparenza, aria o espressione [...] Atteggiamento è raramente limitato allaspetto esteriore, indicando per lo più un complessivo modo di essere interiore che traspare anche all'esterno:[...] Più specifico per le condizioni di salute è cera: avere una bella o una brutta c. indica il colorito e l'espressione facciale di chi si sente bene o male. 
Then there is a second, picturesque and metaphorical layer, with strong animal connotations; and, finally, a third more abstract layer, such as 'aspetto', 'fisionomia', 'fattezze, which is used in theoretical or official discourses rather than in conversation. This multiplicity is not an exclusive feature of the Italian language, surely it applies elsewhere as well, but of course with different details; however, this theme should certainly be deepened with targeted lexicological research.

\section{Metaphors of the face}

One feature is striking in this review of the Italian terms and also of the main words in other languages listed above: in none of them is the face presented in relation to the subjectivity, the self, the personality, the true character of the individual, the real person. ${ }^{12}$ On the contrary, the face appears like a surface opposite to the world, which hides the intentions, thoughts and emotions of the subject. Erving Goffman $(1955,1967)$ has introduced an important sociological reflection on this superficial and external character of the face. He proposed to focus on an important relational aspect of social life, namely the interaction between subjects defined for their role, which he characterized using the metaphor of 'face', as common language often does. According to Goffman's "dramaturgical" metaphor, the face is a mask which is worn according to the audience and the variety of social interaction. This is the most important element of the "scene" in the "play" that regulates the way people appear to one another in social life. The face indicates a certain role, a position, a carefully constructed social identity. People strive to keep the face they have created in social situations and they see the prospect of "losing it" as a grave danger. They are emotionally attached to their faces, so they feel good while these are kept; face "loss" results in emotional pain, so in social interactions people cooperate using courtesy strategies to keep each other's face.

The micro-sociological theory, however, borrowed these face-based metaphors from a widespread linguistic practice. Since Dante (Purgatorio, XXIII, 101), we will find that the word 'sfacciato' ('brazen', composed of the privative 's' and 'face': 'without a face') in Italian indicates a "person who has no modesty, restraint, shame" (Cortellazzo, Zoli 1988: 1190) and has a very negative connotation. Someone "faceless" is a disreputable individual. The notion of 'losing face' is present in Japanese (面目を失 j menboku wo ushinau); in Persian (Aab ro rizi ى ى 'losing the face's water'); in various South Slavic languages, as in Serbian, Croatian and Bulgarian (безобразен, bezobrazan); in Chinese (diu mianzi

12 For a semiotic and philosophical-linguistic investigation of this last linguistic field, see Volli in print. 
丢面子). ${ }^{13}$ The notion is especially important and widely studied in Chinese culture (Zuo 1997; Huang 1987); there is, for example, a widespread proverb "Men cannot live without a face just as trees cannot live without bark" (ren hou lian, shu hou pi-人后脸，树后皮). In Arabic, the correlative expression 'hafiza $m \bar{a}$ 'al-wajh' (حفظ مساء الوجـه), which literally translates as 'save the face's water', is used to mean 'to save face'.

The vast diffusion of this metaphor is undoubtedly striking. George Lakoff and Mark Johnson (1980) suggest that the explanation is to be found in the metonymic relation that replaces a part (the face) for the whole (the whole human being). It is true that if you ask someone to exhibit a photograph and he shows you a picture of his face, you are satisfied, yet this does not happen if he shows you the image of his back or of the whole body without the face. Yet beyond the purely material identification, 'face' indicates a social position, a widespread esteem, a role abstract qualities that can be lost and recovered, not just the physical individuality which is much more rooted and more or less indelible. Another clue in this sense is the use of the word 'interface' that used to denote the surface of separation between two liquids, but in the 1980s came to mean the contact between two computers and then the instrument of human-machine communication, with the implication that what appears on the interface does not represent the computer processes, but forms a representation or translation adapted to the user's needs. ${ }^{14}$ The interface, as the face, is something between the poles of communication that both expresses and hides.

In other words, not only in microsociology but also in everyday life, the face is mostly perceived as a mask. This is a widespread term worth dwelling on for a moment. The root used in most Indo-European languages (Italian 'maschera', French 'masque', English 'mask', Spanish 'mascara', German 'Maske', Russian 'маска', etc.) has an unclear etymology. As Mariella Canzani writes in a note published on 15 March, 2020 for the linguistic consultancy editorial staff of the "Accademia della Crusca", the most important institution dedicated to the Italian language: ${ }^{15}$

13 A repertoire of other similar linguistic traces can be obtained from https://en.wikipedia. org/wiki/Face_(sociological_concept); last accessed on 21 February 2021.

14 "The place at which independent and often unrelated systems meet and act on or communicate with each other; the means by which interaction or communication is achieved; a surface forming a common boundary of two bodies, spaces, or phases" (https://www.merriamwebster.com/dictionary/interface).

15 The source: https://www.facebook.com/notes/353039995777856/ was last accessed on 22 February 2021. 
The main hypotheses are two, not in contrast with each other: one suggests the derivation from a pre-Indo-European form masca 'soot, black ghost' (FEW reconstructs a base ${ }^{*}$ mask 'dark'), the other suggests the derivation from masca 'witch', a regional expression of the Ligurian and Piedmontese area. Masca in turn derives from the late Latin $\operatorname{masca}(m)$, a noun used in the same meaning, a term documented by written sources starting from the mid-seventh century, first attested in the Edict of Rotari (Lex longobardorum I, 11: strigam, quodest mascam), which in turn could be of pre-Roman origin. From the original meaning of 'witch' we will arrive later to that of a ghost, a spirit, a disguised aspect to instill fear. The linguistic evolution of the signifier instead led to the addition of an 'r', making the term assume the form first of mascra and then of mascara, an ancient variant attested in the 13th century. According to some scholars, the late Latin masca $(m)$ should be a relict of the pre-Gallic substratum, alternating with ${ }^{\star} b a s c a$, cf. Fr. rebâcher, from Old French.

* rabaschier 'make noise', used about ghosts, from the verb ${ }^{\star}$ bascare that corresponds to the Greek báskein, a term that alludes to magical fascination. Finally, other scholars have suggested a derivation of the etymology from the Arabic phrase maschara or mascharat, 'fool, hoax', deriving from the verb sachira, 'to mock', imported into medieval language from the Crusades. However, the presence of this word in texts prior to the Crusades demonstrates the inaccuracy of the Arabic derivation of this family of words.

And yet, as Canzani notes again, "the term of classical Latin to indicate the theatrical mask used by the histriones (actors) was persona. It is a loan, through the Etruscan phersu, from the Greek prósopon", a word which we have already encountered in the list of the main terms corresponding to 'face' in various languages, because its first meaning is precisely "'forehead, face, face, and then 'mask' and 'character"' There is, thus, an important etymological relation between 'mask', 'person' and 'face', which was also exploited by the great Italian playwright Luigi Pirandello when he entitled a collection of his theatrical texts Naked Masks, proposing a double oxymoron double, because the mask is an inanimate object and nudity applies only to human beings; and because a face covered by a mask obviously cannot be naked.

\section{Conclusion: Some philosophical consequences}

What interests us most in this exploration of the metaphorical use of the face as a mask is the fact that it is made possible by a fundamental and often insufficiently emphasized semantic trait that characterizes theses notions, their exteriority, which is a fundamental point in the philosophical analysis of the face. This theme of the exteriority of the face was developed by Levinas in terms of the 'transcendence' of the other: 
The face escapes from possession, from my power. In its epiphany, in expression, the sensitive, which is still graspable, changes into total resistance to the grip. This change is only possible thanks to the opening of a new dimension. In fact, resistance to grip is not produced as an insurmountable resistance, as the hardness of the rock against which the effort of the hand is useless, as the distance of a star in the immensity of space. The expression that the face introduces into the world does not challenge the weakness of my power, but my power of power. The face, still a thing among things, opens a gap in the form that delimits it. Which means concretely: the face speaks to me and thus invites me to a relationship that has no common measure with a power that is exercised, even if it is enjoyment or knowledge. [...] When I refer to the face, I don't just mean the colour of the eyes, the shape of the nose, the redness of the lips. Stopping here I still contemplate only some data; but even a chair is made of data. The true nature of the face, its secret lies elsewhere: in the question he asks me, a question that is both a request for help and a threat. (Levinas 1961: 85; my translation, U. V.)

Levinas recognizes that the condition of the "transcendence" of the face of others is "its secret" which always "lives elsewhere": elsewhere than the world of things of which it is also a part. This is its "exteriority", that is, the fact that we do not have direct access to the other through the face, that the other always exceeds it. If anything, the face should be assimilated to a "trace" ["the presence of what, properly speaking, has never been, of what has always already passed" (Levinas 1972: 89)] and is the condition of all signification:

It (the expression) presents the signifier. The signifier, the one who gives a sign, is not signified. It is necessary to have already been in an area of signifiers, for the sign to appear as a sign. The signifier must therefore present itself before any sign, in itself - as a face. (Levinas 1961: 186; my translation, U. V.)

This condition of excess and exteriority is therefore very similar to that of the linguistic signifier, which is never transparency of the sign; in language the signifier is always opaque and this condition grounds the principle of arbitrariness. Meaning exceeds its signifier, it is not determined by it, just as the human being exceeds his/ her face, he/she can think and feel and be more than what he/she lets to be seen. This condition of transcendence, which filters the sense of the face and is eminently expressed in the linguistic capacity of humans, is what underlies their freedom the human exception.

With the term 'exception' I refer to the logical sense of this word, that is as "a case to which a rule does not apply"16, without any reference to the 'state of exception' mentioned in Agamben 2005, because this is a juridical measure taken

16 The definition derives from https://www.merriam-webster.com/dictionary/exception. 
by some authority, while I am referring to the attribution to human beings of a permanent status that frees them from the causal system that we attribute to all things of the world, including living beings. If all human behaviour were simply a consequence of causes, as is the case with avalanches, earthquakes or hurricanes, we could not attribute to it evaluations or responsibilities, we could not speak of faults and merits. On the other hand, when we do so and we hold human beings responsible for the consequences of their behaviour (which is not so with mountains and seas, nor even with snakes or microbes), we implicitly, rightly or wrongly, believe them to be capable of a freedom of choice that other things in the world do not have. In short, we presuppose a gap between causes and behaviour, just as there is a gap between the signifier and meaning and between the face and the subject.

This is the "human exception", which of course requires explanations from philosophy (or from theology, or from science). In Volli 2010 and Volli 2013 I supported the thesis that this "transcendence" with respect to the causal system, that is attributed to human beings, is derived from the linguistic competence that characterizes them (another significant "human exception"), because language is characterized by arbitrariness, that is, by the lack of causal connection between expression and meaning (in Saussure's terms: the signifier and the signified). There is a degree of freedom in the process of signification which makes the meaning always partially indeterminate. The absence of meaning from the expression is decisive for this arbitrariness and it also recalls the transcendence or absence of the subject in the face.

This relationship, not at all trivial, but evident between language and the face is also underlined by Giorgio Agamben in a short essay written in $1996,{ }^{17}$ now included in a collection of political essays:

What the face exposes and reveals is not something that could be formulated as a signifying proposition of sorts, nor is it a secret doomed to remain forever incommunicable. The face's revelation is revelation of language itself. Such a revelation, therefore, does not have any real content and does not tell the truth about this or that state of being, about this or that aspect of human beings and of the world: it is only opening, only communicability. To walk in the light of the face means to be this opening- and to suffer it, and to endure it. Thus, the face is, above all, the passion of revelation, the passion of language. Nature acquires a face precisely in the moment it feels that it is being revealed by language. (Agamben 2006[1996]: 93)

17 I thank the anonymous reviewer who prompted me to develop my analysis further at this point. 
Agamben's reasoning is somewhat different from the line of analysis I have proposed till now and also differs from that of Levinas. For Agamben (1996: 91), "the face is at once the irreparable being-exposed of humans and the very opening in which they hide and stay hidden". This opening is also common to animals, but "only human beings want to take possession of this opening, to seize hold of their own appearance and of their own being being-manifest [...]. Language is this appropriation, which transforms nature into face". The emphasis here is not about the "hiding in the opening", namely absence in the appearance, which I have already discussed above, but about the "appropriation" and "possession" of this opening, which can be understood as the strategic games of the appearance studied by Goffman under the name of 'face'. This leads Agamben (1996: 91) to think that "the face is the only location of community, the only possible city", in particular today it is a "city", a polis that Agamben criticizes in political terms that we will not discuss here. In Agamben's terminology, the individual and expressive level that I have analysed so far is the 'visage' with which "the face does not coincide":

The only face to remain uninjured is the one capable of taking the abyss of its own communicability upon itself and of exposing it without fear or complacency. This is why the face contracts into an expression, stiffens into a character, and thus sinks further and further into itself. As soon as the face realizes that communicability is all that it is and hence that it has nothing to express - thus withdrawing silently behind itself, inside its own mute identity - it turns into a grimace, which is what one calls character. Character is the constitutive reticence that human beings retain in the word; but what one has to take possession of here is only a non latency, a pure visibility: simply a visage. The face is not something that transcends the visage: it is the exposition of the visage in all its nudity, it is a victory over character it is word. (Agamben 1996: 95)

In the face there would therefore be a tension between support and function, "the duality of proper and improper, of communication and communicability, of potentiality and act. The face is formed by a passive background on which the active expressive traits emerge". In this regard, Agamben cites a long passage from Rosenzweig's Der Stern der Erlösung, where the German philosopher sees in the face a symbolic instance of the "Star of Redemption", consisting of two triangles: a "basic" one which takes shape in the alignment of the sense organs (eyes and mouth), which is "pure receptivity", and another, "superimposed" one, composed of the other parts "whose activity quickens the rigid mask of the first" (see Rosenzweig 1970[1921]: 422-23). Agamben's (1996: 97) comment shifts this symbolic towards a socio-political vision of our time: "In advertising and pornography (consumer society), the eyes and the mouth come to the foreground; in totalitarian states 
(bureaucracy), the passive background is dominant (the inexpressive images of tyrants in their offices)."

Agamben's analysis is best understood by thinking of the great tradition of philosophical anthropology that starts with Aristotle (Nicomachean Ethics I.13, 1102a5-1103a10), for which, apart from the contemplative life of the philosopher, the fullness of the human is reached in the "vita activa" of public action, the living presence of the person in the public sphere (Arendt 2013[1958]), and this action in turn is made possible mainly by language. The face thus becomes the place of this opening to the polis and it undergoes its vicissitudes, in particular as regards the general object of Agamben's critique - modern Western society.

This is therefore a philosophy of the face that works exclusively on its general social dimension: not on the face of the individual human being and on his relationship with his identity and with his neighbours, but on the regime of visibility that faces realize and endure in relation to circumstances of collective life. In short, the face for Agamben is a certain way of acting on others, a communication tool that, like all media, can be emptied to the point of only expressing its own communicability. However, there is at least one other point of view which considers the face as a fundamental place of personal identification, originating from Lacan's mirror phase (Lacan 1949).

This approach and the aporias it opens up are the central theme of the path proposed in this paper. The face appeared to us as a certain placeholder of absence, a certain support of the not being all there of the person who is present; its mask dimension allows it to play differently from that of simply present objects. It is never a neutral object, while it is always the bearer of values and the object of evaluations; in a certain sense it is the original model of the communication of values. Therefore, it can be an actual sign of the person, bringing to others some of his qualities, certain of his values, his current thymic position. With two caveats: that the sign can never be identical to its object (as Plato already claimed in Cratylus, 432a), but must always highlight some of its sides, a face; and that the person (or prosopon - namely his/her face) can never be identical to the human being it represents socially, but highlights some aspects, some faces of this human being, or even constructs them.

\section{References}

Agamben, Giorgio 2000[1996]. Means without End: Notes on Politics. (Casarino, Cesare; Binetti, Vincenzo, trans.) Minneapolis: University of Minnesota Press. Agamben, Giorgio 2003. Stato di eccezione. Torino: Bollati Boringhieri. Beaney, Michael 2013. What is Analytic Philosophy? Oxford: Oxford University Press. https://doi.org/10.1093/oxfordhb/9780199238842.013.0039 
Arendt, Hannah 2013[1958]. The Human Condition. Chicago: University of Chicago Press. Bird, Alexander; Tobin, Emma 2008. Natural kinds. In: Zalta, Edward N. (ed.), The Stanford Encyclopedia of Philosophy. Stantford: The Scholarly Publishing and Academic Resources Coalition.

Campanini, Giuseppe; Carboni, Giuseppe 1993. Vocabolario Latino Italiano / Italiano Latino Torino: Paravia.

Colonna, Barbara 1997. Dizionario etimologico della lingua italiana. Roma: Newton.

Cortellazzo, Manlio; Zolli, Paolo 1988. Dizionario etimologico della lingua italiana. Bologna: Zanichelli.

Daly, Chris 1998. Natural kinds. In: Craig, Edward (ed.), Routledge Encyclopedia of Philosophy. Vol. 6. London: Routledge, 682-685.

Darwin, Charles 2009[1872]. The Expression of the Emotions in Man and in the Animals. London: Penguin. https://doi.org/10.1017/CBO9780511694110

Eco, Umberto 1983. Semiotics and the Philosophy of Language. Bloomington: Indiana University Press.

Huang, Shuanfan. 1987. Two studies of prototype semantics: Xiao 'Filial Piety' and Mei Mianzi 'Loss of Face'. Journal of Chinese Linguistics 15: 55-89.

Ferraris, Maurizio 2009. Documentalità. Perché è necessario lasciar tracce. Roma-Bari: Laterza.

Gabrielli, Aldo 1967. Dizionario dei sinonimi e dei contrari. Milano: Istituto Editoriale Italiano.

Goffman, Erving 1955. On face-work. Psichiatria 18(3): 213-231. https://doi.org/10.1080 /00332747.1955.11023008

Goffman, Erving 1967. Interaction Ritual: Essays in Face-To-Face Behavior. Chicago: Aldine.

Lacan, Jacques 1949. Le Stade du miroir comme formateur de la fonction du Je: telle qu'elle nous est révélée dans l'expérience psychanalytique. Revue française de psychanalyse 13: 449-455.

Lakoff, George; Johnson, Mark 1980. Metaphors We Live By. Chicago: The University of Chicago Press.

Levinas, Emmanuel 1961. Totalité et infini: Essai sur l'extériorité. La Haye: Martinus Nijhoff.

Levinas, Emmanuel 1972. Humanisme de l'autre homme. Montpellier: Fata Morgana.

Lotman, Juri 2011[1967]. The place of art among other modelling systems. [Tezisy $\mathrm{k}$ probleme "Isskusstvo v ryadu modeliruyuschih sistem".] (Pern, Tanel, trans.) Sign Systems Studies 39(2/4): 249-270. https://doi.org/10.12697/SSS.2011.39.2-4.10

O'Riley, Tim 1998. Representing Illusions: Space, Narrative and the Spectator in Fine Art Practice. London: Chelsea College of Art and Design.

Prum, Richard 2017. The Evolution of Beauty. New York: Doubleday.

Quine, Willard 1960. Word and Object. Cambridge: The MIT Press.

Rosenzweig, Franz 1970[1921]. The Star of Redemption. (Hallo, William W., trans.) New York: Holt, Rinehart and Winston.

Searle, John 1995. The Construction of Social Reality. New York: Free Press.

Volli, Ugo 2010. Al di là dell'essenza, il linguaggio. Quaderni laici 1: 113-119.

Volli, Ugo 2013. Riflessione e trascendenza di una maschera. In: Leone, Massimo; Pezzini, Isabella (eds.), Semiotica della soggettività - Per Omar (I Saggi di Lexia II). Roma: Aracne, 265-278. 
Volli, Ugo 2020. Invisibile, espressivo e necessario Metafore del volto divino nella Bibbia ebraica. Lexia (Volti Artificiali/Artificial Faces; Leone, Massimo, ed.) 37-38: 557-583.

Volli, Ugo 2021. Di che cosa parliamo quando diciamo 'persona'? - Fra filosofia e semiotica. In: Ponzo, Jenny; Vissio, Gabriele (eds.), Culture della persona: Itinerari di ricerca tra semiotica, filosofia e scienze umane. Torino: Accademia University Press.

Zuo, Bin 1997. Chinese "lian" and "mianzi". Wuhan: Huazhong Normal University Press.

\section{Трансцендентность лица: лингво-семиотический путь}

В начале статьи мы анализируем термины, используемые для обозначения лица в разных языках, в частности, в итальянском, сравнивая их с определениями, предложенных некоторыми авторитетными словарями, а также с их этимологией. Это исследование приводит к примечательным результатам: во-первых, оказывается, что термин «лицо» имеет материальное значение, но в то же время является социальным объектом; во-вторых, подчеркивается важность коммуникативной функции, которая делает лицо похожим на маску, что, в некотором роде, напоминает арбитрарность языка. Все это говорит о том, что философский статус лица - это «трансцендентность», которая является условием того состояния свободы, которое мы приписываем себе и которое можно определить как «человеческое исключение».

\section{Näo transtsendentsus: semiootilis-lingvistiline tee}

Artikkel algab nägu tähistavate terminite vaatlemisega erinevates keeltes, eriti itaalia keeles, kõrvutades neid definitsioonidega, mida pakuvad mõned autoriteetsed sõnaraamatud ja ka nende etümoloogiaga. Need vaatlused annavad tähelepanuväärseid tulemusi: esiteks ilmneb, et nägu on tõepoolest termin, millel on materiaalne tähendus, ent samal ajal on tegu sotsiaalse objektiga; teiseks tuleb esile kommmunikatiivse funktsiooni olulisus, mis muudab näo sarnaseks maskiga ning mõnel moel ka keele arbitraarsusega. Kõik see viitab asjaolule, et näo filosoofiline staatus on "transtsendentsus", mis on selle vabadusseisundi tingimus, mida me omistame enestele ning mida võib defineerida kui "inimlikku erandit". 